\title{
Trials on Acclimatization of Tissue Culture Derived Date Palm Plants (Phoenix dactylifera $L)$.
}

\author{
Hagagy,N.A.A.* ; Zayed,N.S.**:Abdel AttY,Y.A.*: Youssef, D. A.B. \\ Benha University, Faculty of Agriculture.Horticulture, Department* \\ National Research Center, Agriculture Section, Dokki, Egypt**
}

\begin{abstract}
Different light intensities i.e.1000,2000 and 3000 lux ; agricultural media i.e. vermiculite, sand , and peat moss ; pot sizes i.e. small \&large as well as pot opening types i.e. Basal and longitudinal were trials applied to enhance acclimatization and production of healthy \& vigorous plants of Barhi cv. date palm plantlets. Results indcate that using light intensity at 2000 lux improved most parameters under investigation. Also, most of combined treatments of agricultural media were superior in enhancing excellent results for most acclimatization parameters of Barhi cv.date palm. Moreover, using combination of either Basal or longitudinal pot opening types with small pot size during acclimatization stage of Barhi date palm improved most parameters under study.
\end{abstract}

Key words: Date palm, acclimatization, light intensities, Agriculture media, pot size, in vitro and ex vitro

\section{Introduction}

Barhi is one of the most commercial and popular date cultivars in the world. One of the main problems of in vitro propagation is acclimatization of tissue culture derived plantlets. Rooting and subsequently acclimatization stages were considered the most important stages in the commercial scale.

Acclimatization of plantlets derived from tissue culture confirmed the efficiency and importance of this method. Subculturing of rooted shoots on MS salts solution and increasing light intensity enhanced plantlets photosynthesis and then changing it from heterotrophic to autotrophic status. Pierik ,(1987) revealed that the survival percentage of date palm plantlets was low for many reasons, i.e. the cuticle (wax layer) is often poorly developed because of the high relative humidity which reached up to $90-100 \%$ in vitro .

Khieralla and Bader (2007) acclimatization of plantlets derived from tissue culture confirmed the efficiency and importance of this method. The subculture of rooted shoots into MS salts solution and increasing light intensity enhanced the plantlet photosynthesis and then changing it from heterotrophic to autotrophic status of date palm.

El-Deeb and Sourour (2002) studied subjecting of in vitro plantlets during acclimatization to different light intensities (2000, 4000, 6000 and 8000 lux) and different darkening treatments (activated charcoal (AC), surface coverage's (SC), outer coverage (OC) and their combinations). Data indicated that, subjecting of in vitro plantlets to 6000 and 8000 lux as well as using AC with OC maximized most of The growth parameters of Zaghloul plantlets. El-Bahr, et.al. (2003) reported that the highest survival percentage was recorded with plantlets growing on 3/4 strength liquid MS medium, compared with the other medium strengths.
The percentage of adapted then acclimatized plants (depending on the appearance of the true leaves) were $80 \%$ after 9 months of transplanting to the greenhouse. The highest survival percentage (23\%) was observed with washed sand + peat moss + vermiculite + perlite (1:1:1:1).

The main objectives of this investigation are determining the best light intensity, agriculture media combination, pot size and opening type for in vitro and in vivo acclimatization stage of date palm plantlets of Barhi CV.

\section{Material and Methods}

The present study was conducted during the period from 2012 to 2015 at Tissue Culture Unit, Horticulture Department, Faculty of Agriculture; Benha University .This work studied the effect of light intensity, agricultural media, pot sizes, and Pot opening types on acclimatization of in vitro resultant date palm plantlets Barhi CV.

During acclimatization stage the following experiments were investigated:-

\section{1-Effect of light intensity}

Different light intensities i.e.1000, 2000 and 3000 lux, through using different numbers of white cool fluorescent lamps for 16 hours of light and 8 hours of dark were evaluated to find out the most suitable light intensity inducing the highest shoot length \& thickness and rooting primordial parameters.

The following experiments were applied under acclimatization incubation room conditions (temperature 30C).

2-Effect of agricultural media

Different steps of preparation of in vitro plantlets to ex vitro are applied as recommended according to Abdel-Gawad(2001).Ex vitro plantlets of date palm plants were planted in suitable pot filled 
with sterilized vermiculite, sand, or peat moss either alone or in combinations as follow.

$1-100 \%$ vermiculite

$2-100 \%$ sand

$3-100 \%$ peat moss

4-50\%vermiculite + 50\%sand

5- 50\%vermiculite $+50 \%$ peat moss

$6-50 \%$ sand $+50 \%$ peat moss

$7-25 \%$ vermiculite $+50 \%$ sand $+25 \%$ peat moss

To detect the best combination enhanced the highest percentages of survival and encouraging the most suitable growth parameters.

\section{3-Effect of different pot sizes and opening types:-}

The date palm plantlets were planted in different pot sizes (small \& large )and pot opening types ( longitudinal and solid ) filled with the best combined agriculture media consists of $25 \%$ vermiculite $+50 \%$ sand $+25 \%$ peat moss to determine the best pot size and pot opening type.

\section{Date and calculations}

Greening and Necrosis parameters were tested as scores. These scores were given as follow for Greening : negative results $=1$, below average $=2$, average $=3$, above average $=4$ and excellent results $=5$ However, the reverse was true for scores of Necrosis (according to pottino, 1981). On the other hand, Shoot \& Root lengths were measured as cm, Shoot \& Root thickness as mm. while, leaves were calculated as number.

\section{Survival percentage was calculated as}

Survival $\%=$ No. of survived plants / total no. of starting plants $\times 100$

Statistical analysis:-

All treatments used in this study were arranged in a complete randomized block design and replicated 4 times with 3 jars for each replicate. The obtained date were subjected to analysis of variance and statistically analyzed according to Duncan's multiple range test (Duncan, 1955) at 1\%level.

\section{Results and Discussion}

\section{1-Effect of light intensity:-}

Table (1) and photo (1) show the effect of different light intensities on growth parameters of in vitro date palm plantlets. It is quite evident that using of light intensity at 2000 lux succeeded in inducing a significant increase in most parameters under study (Shoot length, Root length, Root number and
Greening) as compared with the other light intensities. Also, using light intensity at 3000 lux was significantly superior in increasing Shoot thickness as compared with the others.

However, Necrosis was significantly decreased when light intensity at 1000 lux was used. On the other hand, different light intensities failed to induce any statistical differences as Number of leaf parameters were considered.

Generally, the obtained results indicate that using light intensity at 2000 lux improved most parameters under investigation. This may be due to the increasing light intensity enhanced the plantlets photosynthesis and then changing it from heterotrophic to autotrophic status. These results are in co-ordination with the findings of Khieralla and Bader (2007). They stated that sub-culturing of rooted shoots into MS salts solution and increasing light intensity enhanced the plantlet photosynthesis and then changing it from heterotrophic to autotrophic status of date palm.

\section{2-Effect of different agricultural media:-}

It is clear from Table (2) and photo (2) that all combination treatments of agricultural media were significantly more superior in improving most parameters under study as it increased the percentage of survival, Shoot length \&thickness and number of leaves as compared with the other used alone agricultural media treatments in both seasons. Also, combination treatment of $25 \%$ vermiculite $+50 \%$ sand $+25 \%$ peat moss induced the best results for most parameters under study. These results may be due to increase in the amount of formed root system which enhance absorption ability and in turn enhanced growth parameters. These results are partially in agreement with the findings of Omar (1988) on date palm, Abdel-Gawad (2001) on Pyrus communis and Baaya et at (2002) on date palm. They found that combination of agricultural media induced the highest percentage of survival, plantlets length, shoot thickness and Greening parameters. Also, the obtained data somwhat go in line with the findings of ElBahr, et.al. (2003).They reported that the percentage of adapted then acclimatized plants (depending on the appearance of the true leaves) were $80 \%$ after 9 months of transplanting to the greenhouse. The highest survival percentage (23\%) was observed with washed sand + peat moss +vermiculite + perlite (1:1:1:1).

Table 1. Effect of different light intensities on growth parameters of in vitro date palm plants

\begin{tabular}{|c|c|c|c|c|c|c|c|}
\hline $\begin{array}{l}\text { Growth } \\
\text { parameters } \\
\text { Light } \\
\text { intensities }\end{array}$ & $\begin{array}{l}\text { Necrosis } \\
\text { (scores) }\end{array}$ & $\begin{array}{l}\text { Shoot } \\
\text { length } \\
(\mathrm{cm})\end{array}$ & $\begin{array}{l}\text { Shoot } \\
\text { thickness } \\
(\mathrm{cm})\end{array}$ & $\begin{array}{l}\text { No. of } \\
\text { leaves } \\
\text { (number) }\end{array}$ & $\begin{array}{l}\text { Root } \\
\text { length } \\
(\mathrm{cm})\end{array}$ & $\begin{array}{l}\text { Root } \\
\text { number } \\
\text { (number) }\end{array}$ & $\begin{array}{l}\text { Greening } \\
\text { (scores) }\end{array}$ \\
\hline 1000 & $2.95 \mathrm{C}$ & $5.23 \mathrm{C}$ & $1.35 \mathrm{C}$ & $3.50 \mathrm{~A}$ & $4.83 \mathrm{~B}$ & $6.00 \mathrm{~B}$ & $3.00 \mathrm{~B}$ \\
\hline $\begin{array}{l}2000 \\
3000\end{array}$ & $\begin{array}{l}3.50 \mathrm{~B} \\
4.03 \mathrm{~A}\end{array}$ & $\begin{array}{l}7.18 \mathrm{~A} \\
5.88 \mathrm{~B}\end{array}$ & $\begin{array}{l}1.73 \mathrm{~B} \\
2.43 \mathrm{~A}\end{array}$ & $\begin{array}{l}3.25 \mathrm{~A} \\
3.50 \mathrm{~A}\end{array}$ & $\begin{array}{l}6.18 \mathrm{~A} \\
4.83 \mathrm{~B}\end{array}$ & $\begin{array}{l}7.75 \mathrm{~A} \\
6.25 \mathrm{~B}\end{array}$ & $\begin{array}{l}4.25 \mathrm{~A} \\
2.25 \mathrm{C}\end{array}$ \\
\hline
\end{tabular}

Means followed by the same letter (s) within each parameter are not statistically different at $1 \%$ level 


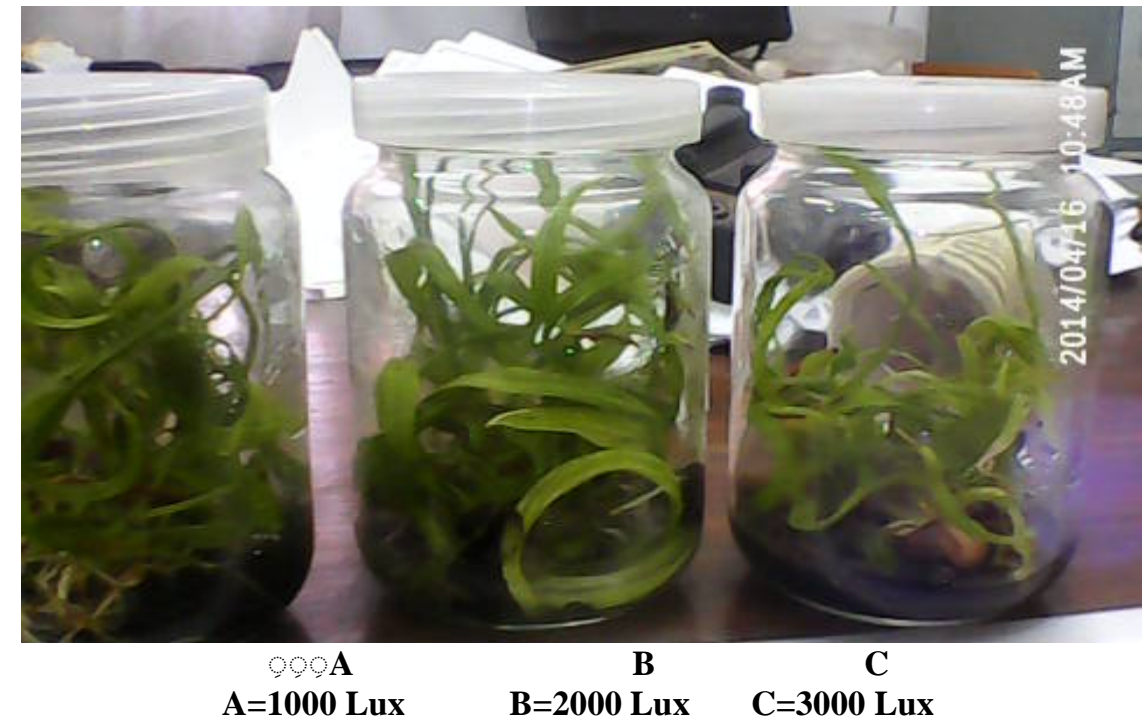

Photo (1) Effect of different light intensities on in vitro Barhi date palm

2-Effect of different pot sizes and opening types:-

Data in Table (3) show the effect of different pot sizes and types on survival percentage and growth parameters of in vivo date palm plants during 2013 and 2014 seasons. It is obvious from Table (3-

A) that using large pot size was more superior than small pot in increasing Stem length in both seasons as well as Stem thickness in the first season. On the other hand, No. of leaves took statistically the other way around during the first season. Moreover, statistical differences were lacking between both pot sizes under study when survival percentages during both seasons and both Stem thickness \& and Number of leaves parameters during the second season.

Table 2. Effect of different agricultural media on survival percentage and growth parameters of in vivo date palm plants acclimatization during 2013 \& 2014 season

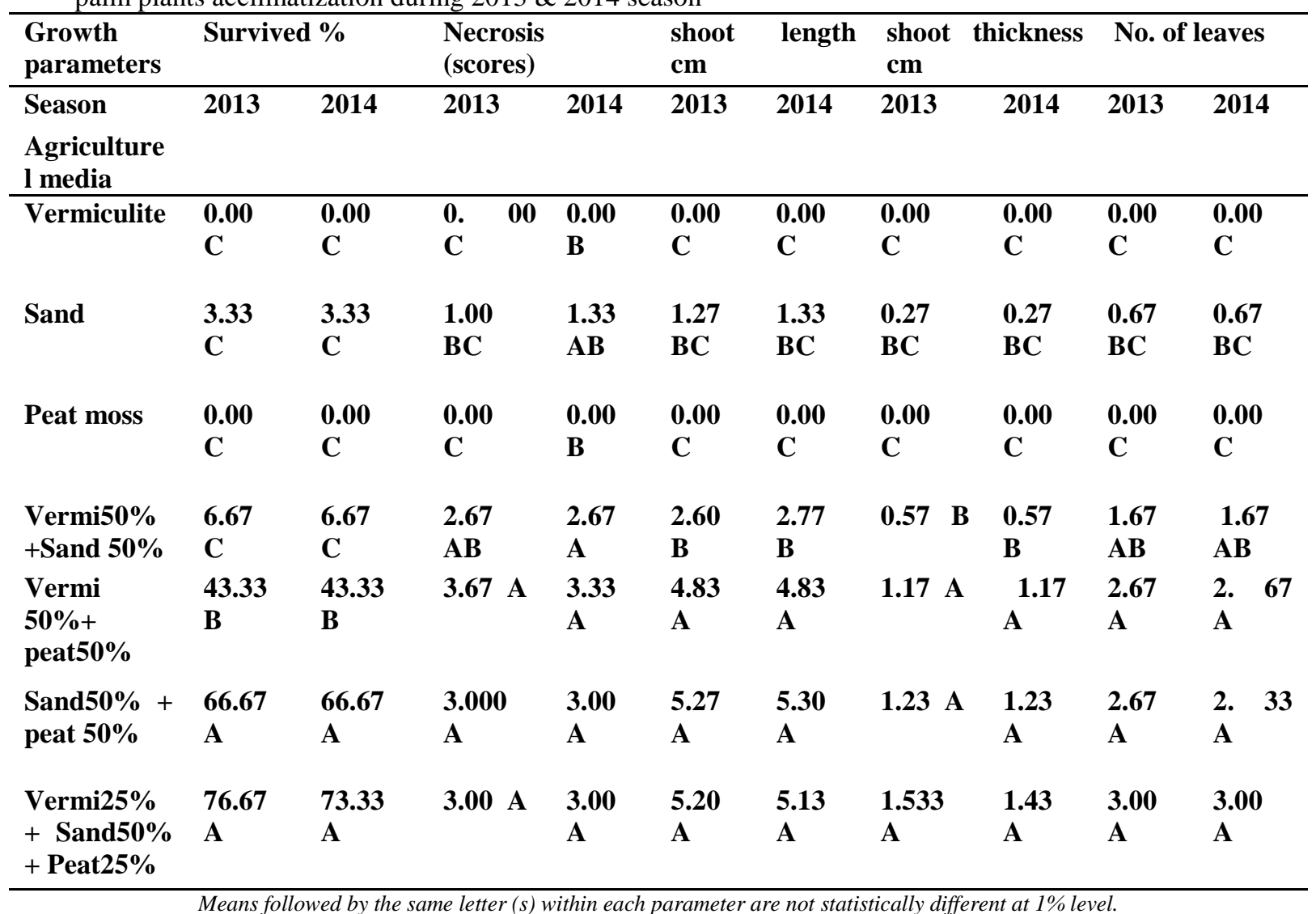

Means followed by the same letter (s) within each parameter are not statistically different at 1\% level. 


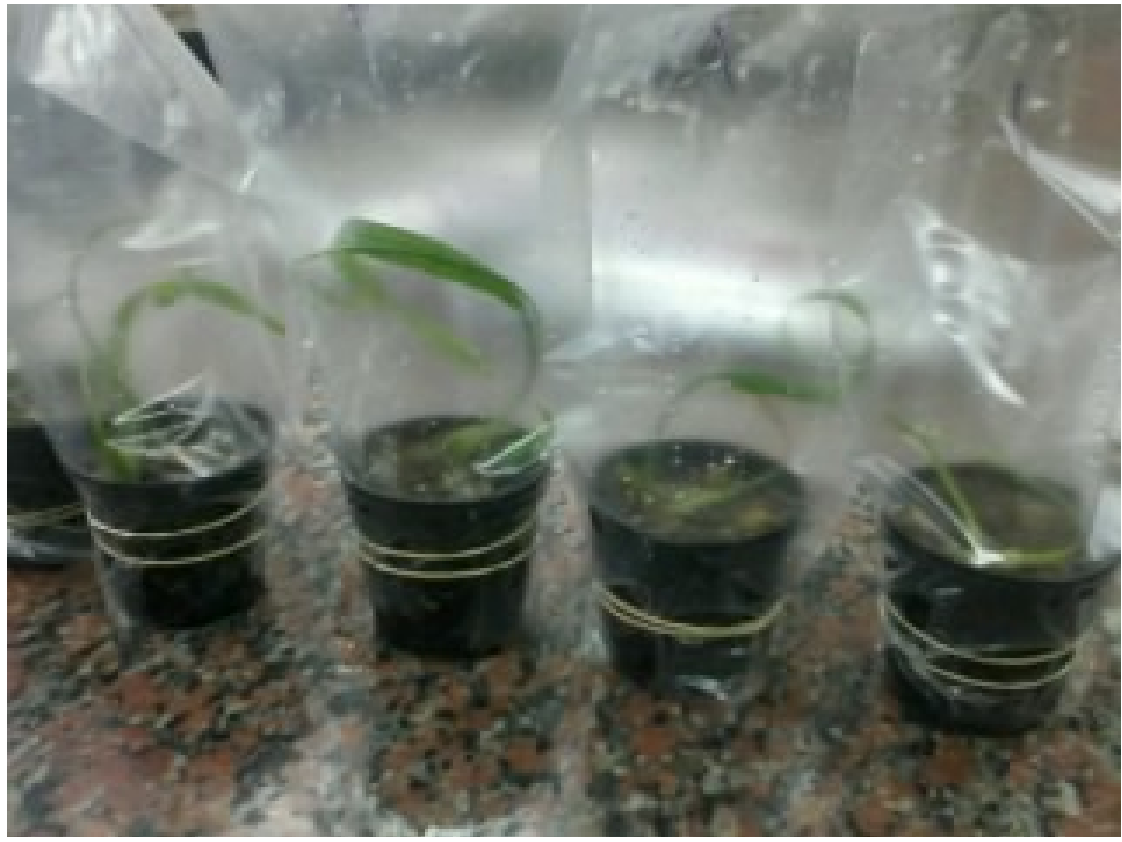

Photo (2) Effect of agriculture media combinations

Table (3): Effect of different pot sizes and types on survival percentage and growth parameters of in vivo date palm plants during 2013 and 2014 seasons.

Table (3-A): Effect of pot sizes:-

\begin{tabular}{|c|c|c|c|c|c|c|c|c|}
\hline \multirow{2}{*}{$\begin{array}{l}\text { Measurements } \\
\text { seasons }\end{array}$} & \multicolumn{2}{|c|}{ Survived \% } & \multicolumn{2}{|c|}{ Stem length(cm) } & \multicolumn{2}{|c|}{ Stem thickness(cm) } & \multicolumn{2}{|c|}{$\begin{array}{l}\text { No of leaves } \\
\text { (number) }\end{array}$} \\
\hline & 2013 & 2014 & 2013 & 2014 & 2013 & 2014 & 2013 & 2014 \\
\hline \multicolumn{9}{|l|}{ Pot size } \\
\hline \multirow[t]{2}{*}{ small } & $80.00 \mathrm{~A}$ & 63.33 & 4.87 & 5.12 & 1.73 & 1.78 & 4.33 & 3.33 \\
\hline & & A & B & B & B & A & A & A \\
\hline \multirow[t]{2}{*}{ large } & 66.67 & 70.00 & 5.77 & 5.85 & 2.05 & 1.97 & 3.00 & 3.83 \\
\hline & A & A & A & A & A & A & B & A \\
\hline
\end{tabular}

Means followed by the same letter (s) within each parameter are not statistically different at 1\% level

Table (3-B): Effect of pot opening type.

\begin{tabular}{lllllllll}
\hline Measurements & \multicolumn{2}{l}{ Survived \% } & \multicolumn{2}{l}{ Stem length(cm) } & Stem thickness(cm) & $\begin{array}{l}\text { Na of leaves } \\
\text { (number) }\end{array}$ \\
\hline $\begin{array}{l}\text { seasons } \\
\text { Opening type }\end{array}$ & 2013 & 2014 & 2013 & 2014 & 2013 & 2014 & 2013 & 2014 \\
Longitudinal & 76.67 & 83.33 & 6.18 & 6.27 & 1.98 & 2.00 & 3.83 & 4.00 \\
& A & A & A & A & A & A & A & A \\
Basal & 56.67 & 50.00 & 4.45 & 4.70 & 1.80 & 1.75 & 3.00 & 3.17 \\
& B & B & B & B & A & A & B & B \\
\hline
\end{tabular}

Means followed by the same letter (s) within each parameter are not statistically different at $1 \%$ level.

\section{Effect of large pot size with basal opening type}

Meanwhile, data presented in Table (3-B) shows that using of longitudinal opining type improved most parameters under study as it significantly increased Survival percentage, Stem length and Number of leaves in both seasons and Stem thickness in the first season in comparison with basal opening type. On the other hand, statistical differences was lacking when Stem thickness in the second season was considered. Dealing with the interaction between pot sizes and Opening type, it is quit evident from Table (3-c) that using both longitudinal and basal openings with small pot size recorded the highest significant Survival percentage in both season as well as using basal with large pot size in the second season as compared with the other used combinations. On the contrast, using both longitudinal and basal in combination with small pot size significantly induced maximum Stem length \& thickness and Number of leaves in the second season 
as compared with the other combinations. However, using basal with small pots were effective in increasing Stem length \& thickness and Number of leaves as compared with the other combinations used in the first season.

Generally, the obtained results indicate that using both basal and longitudinal with small pot improved most parameters under study. This may be due to open stomata in tissue cultured plants and poor vascular connections between the shoots and roots may cause the most significant water stress during the first few hours of acclimatization in tissue culture plants. Also be realized the in vitro plant has been raised as a heterotrophic while it must be autotrophic in vivo. Sugar must be replaced through photosynthesis. These results are in coordination with the findings of Hussam and Bader (2007), they found that rooted shoots (plantlets) were transplanted in small pots containing a mixture of peat moss and perlite (2:1) and placed in plastic tunnels or in a greenhouse. The survival percentage was $85 \%$ after 3 months when the plants were transferred to bigger pots of Maktom cv. Date palm.

Table (3-C): Effect of the interaction between pot sizes and Opening types on date palm plants.

\begin{tabular}{|c|c|c|c|c|c|c|c|c|c|c|c|c|c|c|c|c|}
\hline \multirow{3}{*}{$\begin{array}{l}\text { Measurem } \\
\text { ents } \\
\text { seasons } \\
\begin{array}{l}\text { Opening } \\
\text { type }\end{array}\end{array}$} & \multicolumn{4}{|c|}{ Survived \% } & \multicolumn{4}{|c|}{ Stem length(cm) } & \multicolumn{4}{|c|}{ Stem thickness(cm) } & \multicolumn{4}{|c|}{$\begin{array}{l}\text { Na of leaves } \\
\text { (number) }\end{array}$} \\
\hline & \multicolumn{2}{|c|}{2013} & \multicolumn{2}{|c|}{2014} & \multicolumn{2}{|c|}{2013} & \multicolumn{2}{|c|}{2014} & \multicolumn{2}{|c|}{2013} & \multicolumn{2}{|c|}{2014} & \multicolumn{2}{|c|}{2013} & \multicolumn{2}{|c|}{2014} \\
\hline & $\mathrm{L}$ & B & $\mathrm{L}$ & B & $\mathrm{L}$ & B & $\mathrm{L}$ & B & $\mathrm{L}$ & B & $\mathrm{L}$ & B & $\mathrm{L}$ & B & $\mathrm{L}$ & B \\
\hline $\begin{array}{l}\text { Pot size } \\
\text { small }\end{array}$ & 73. & 80. & 80.0 & 86. & 5.7 & 6.6 & 5.9 & 6.3 & 1.8 & 2.1 & 2. & 1.9 & 3.3 & 4.3 & 3.6 & 4.3 \\
\hline & 33 & 00 & 0 & 67 & 3 & 3 & 7 & 7 & 0 & 7 & O7 & $3 \mathrm{~A}$ & 3 & $3 \mathrm{~A}$ & 7 & 3 \\
\hline & A & A & A & A & A & A & A & A & $\begin{array}{l}\mathrm{B} \\
\mathrm{C}\end{array}$ & A & A & & B & & $\begin{array}{l}\text { A } \\
\text { B }\end{array}$ & A \\
\hline large & 46. & 66. & 46.6 & 53. & 4.0 & 4.9 & 4.2 & 5.1 & 1.6 & 1.9 & 1.5 & 2.0 & 3.0 & 3.0 & 3.0 & 3.3 \\
\hline & 67 & 67 & 7 & 33 & 0 & 0 & 7 & 3 & 7 & 3 & 0 & $\mathrm{O}$ & 0 & $0 \mathrm{~B}$ & 0 & 3 \\
\hline & B & A & B & B & D & $\mathrm{C}$ & $\mathrm{C}$ & $\mathrm{B}$ & $\mathrm{C}$ & B & B & A & B & & B & B \\
\hline
\end{tabular}

Means followed by the same letter (s) within each parameter are not statistically different at $1 \%$ level.

\section{References}

Abd El-Gawad,N.M.A.(2001) Studies communis on acclimatization of tissue culture commune's pear rootstock. M. Sc .Thesis, Hort. Depart. Fac. of Agriculture, Moshtohor, Zagazig University.

Baaya. M.H.M (2002): Studies on propagation of some fruit species by using tissue culture techniques. M.Sc. thesis, Hort. Depart. Fac. of Agriculture, Moshtohor, Zagazig University.

Duncan's, D.B (1955): Multiple range and multiple F- tests. Biometrics, H: 1-42

EL-Bahar, M.k., H.S.Taha and S.A.Bekheet (2003): In vitro propagation of Egyptian date palm CV. Zaghloul. 1-In vitro rooting and ex vitro acclimatization. Arab Univ. J. Agric. Sci .ll (2) : 689-699.

El-Deeb, M. D. and M. M. Sourour (2002): Rooting and acclimatization of invitro "Zaghloul" date palm (Phoenix dactylifera L.) Annals of Agricultual Science, Moshtohor 40(1):457-460.
Hussam, S. Mand S.M .Bader (2007): Micro propagation of date palm (Phoenix dactylifera L.) var. Maktoom through Direct Organogenesis. Acta Horticulture (1-12)

Khieralla , H.A.M AND S.M.Bader (2007): Micro propagation of date palm (Phoenix dactylifera ) var . Maktoom through direct Organogenesis. Proc. Llld , conf. Date palm. Acta Horticulture 736.pi 213-223.

Omar, M.S (1988): In vitro response of various date palm explants. Date palm Journal 2(2):371-389.

Pierik, R.I.M (1987): In vitro culture of higher plants. Marinus Nizoff . Publishers . Boston.

Pottino, B.G (1981): Methods in plant tissue culture. Dept of Hort Agri. College Maryland University, College Park. Maryland, USA, 829.

Ziv, M, A.Schwartz and D.fleminger (1987):

Malfunctioning stomata in vitreous leaves of carnation (Dianthus caryphyllus ) plant propagated in vitro implications for hardening plant Sci. 52: 127-134 


\section{محاولات لاقمة نباتات نخيل البلح البرحى الناتجه من زراعة الأنسجه}

نبوى أحمد على حجاجى *; نجوى سلمى زايد** ; ياسر عبد الفتاح عبد العاطى* ; دينا أحمد بدير يوسف

جامعة بنها - كلية الزراعة - قسم البساتين

|المركز القومى للبحوث -الثعبة الزراعية -الدقى -القاهره

اجريت دراسات مختلفة على أقلمة نباتات نخيل البلح البارحى الناتج ة من زراعة الأنسجة بهدف أقلمة وتحسين مقاييس النمو لنباتات نخيل البلح

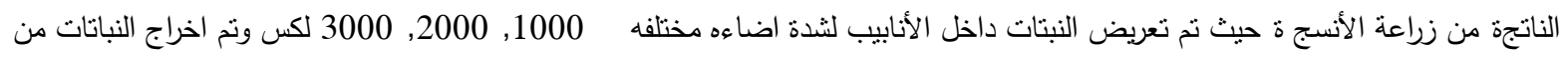
الأنابيب باستخدام الخطوات والمعاملات التى اتبعتها الباحثه نهاد عبد الجواد سنة 2001 وتم زراعتهم على بيئات زراعيه مختلفه (فيرميكيوليت -

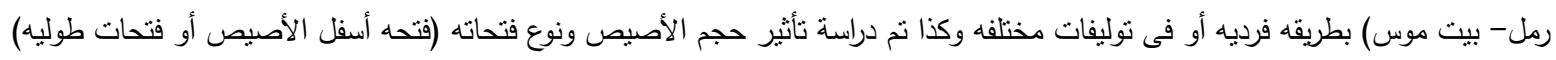

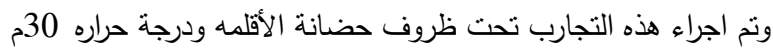
أظهرت النتائج تفوق معنوى لقوة الاضاءه

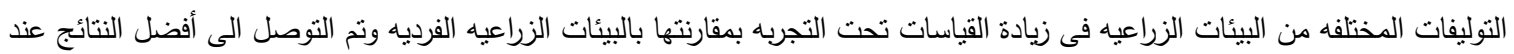

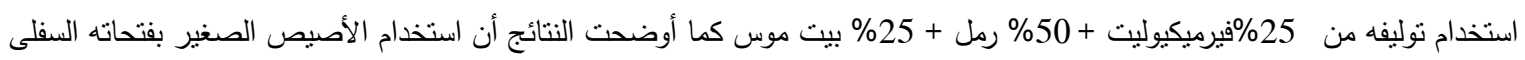
والطوليه ساعدت على تحسين معظم القياسات تحت التجربة . 